(C) 2021, The Authors. Published by Elsevier Inc. and Fass Inc. on behalf of the American Dairy Science Association ${ }^{\circledR}$. This is an open access article under the CC BY-NC-ND license (http://creativecommons.org/licenses/by-nc-nd/4.0/).

\title{
The bioactivity of colostrum and milk exosomes of high, average, and low immune responder cows on human intestinal epithelial cells
}

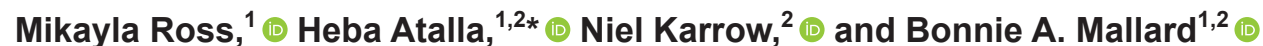 \\ ${ }^{1}$ Department of Pathobiology, Centre for Genetic Improvement of Livestock, University of Guelph, Guelph, ON, N1G 2W1, Canada \\ ${ }^{2}$ Department of Animal Biosciences, Centre for Genetic Improvement of Livestock, University of Guelph, Guelph, ON, N1G 2W1, Canada
}

\begin{abstract}
Bovine milk contains bioactive components that are nutritionally and immunologically important to calves and humans. Dairy cows classified as high (H) immune responders using the patented high immune response technology have higher concentrations of immunoglobulin and specific antibodies in sera and milk compared with average (A) and low (L) responders. MicroRNA post-transcriptionally regulate expression of milk bioactive components and are enriched in extracellular vesicles known as exosomes, which protect them from degradation. The bioactivity of colostrum and milk exosomes at the human intestinal epithelial barrier remains to be explored, particularly in the context of the high immune response technology. Therefore, the purpose of this study was to evaluate the functional role of bovine milk exosomes compared with colostrum exosomes from $\mathrm{H}, \mathrm{A}$, and $\mathrm{L}$ responders at the intestinal interface using human colorectal adenocarcinoma epithelial (Caco-2) cells. Exosomes were isolated by successive ultracentrifugation and confirmed by western blot analysis for the presence of common exosomal proteins (CD9, CD63, and heat shock protein 70). Fluorescent labeling of exosomes using PKH67 dye confirmed their uptake by Caco-2 cells, demonstrating their potential bioavailability. The MTT assays showed that colostrum and milk exosomes maintain Caco-2 metabolic activity and are not cytotoxic to these cells. Specifically, metabolic activity after co-incubation with colostrum and milk exosomes from $\mathrm{H}$ responder cows was significantly greater than after co-incubation with exosomes from $\mathrm{L}$ responders. Caspase 3 activity, an indicator of apoptosis, was significantly lower after co-incubation of Caco2 cells with milk exosomes compared with colostrum exosomes, suggesting that unlike colostrum exosomes, particularly those from $\mathrm{L}$ responders, milk exosomes do not activate the caspase 3 pathway in Caco- 2 cells.
\end{abstract}

Received February 20, 2020.

Accepted August 4, 2020.

*Corresponding author: atallah@uoguelph.ca
This study helps us better understand the functional importance of colostrum and milk exosomes from dairy cows and emphasizes differences in functionality among exosomes from $\mathrm{H}, \mathrm{A}$, and $\mathrm{L}$ immune responders.

Key words: immune response, milk and colostrum exosomes, Caco-2 cell, apoptosis, cell viability

\section{INTRODUCTION}

Bovine colostrum and milk contain bioactive components of significant nutritional and immunological value to humans and calves (Haug et al., 2007; Hill and Newburg, 2015; Korst et al., 2017). Although it produces lower quantities than colostrum, milk still serves as a rich source of immune and developmental factors and functions primarily in gastrointestinal development to support the long-term health of neonates (Khan et al., 2011; Eckert et al., 2015; Meale et al., 2017). Health benefits of bovine milk to humans and calves are proposed to be mediated by the presence of various bioactive components (Haug et al., 2007; Mills et al., 2011; Korst et al., 2017), which are found at varying concentrations in dairy cows classified based on immune responses using the patented high immune response (HIR) technology. The HIR technology identifies dairy cattle as high $(\mathbf{H})$, average $(\mathbf{A})$, or low (L) immune responders using EBV for antibody- and cell-mediated immune responses. Studies have shown that HIR cows have more balanced and robust immune responses, less disease occurrence (Thompson-Crispi et al., 2014; Cartwright et al., 2017), and improved colostrum and milk quality compared with A and L responders (Mallard et al., 2015). Specifically, H cows have significantly greater concentrations of bioactive components, including immunoglobulin and $\beta-\mathrm{LG}$, in their milk (Fleming et al., 2016). Expression of milk bioactive components is post-transcriptionally regulated by small, noncoding RNA molecules (18-23 nucleotides in length) known as microRNA (miRNA; Ogorevc et al., 2009; Liao et al., 2010; Jabed et al., 2012; Li et al., 2012; Wang et al., 2016). MicroRNA have been identified in a variety of biological fluids and are involved in critical biological 
processes, such as those controlling cell differentiation, proliferation, and apoptosis (Bartel, 2004), indicating their functional importance.

Bovine colostrum and milk miRNA are particularly enriched in colostrum- and milk-derived exosomes (Hata et al., 2010; Izumi et al., 2012, 2015; Sun et al., 2013), which are extracellular vesicles 20 to $100 \mathrm{~nm}$ in size originating via the endocytic pathway in a variety of cells (Théry et al., 2009). Exosomes play an important role in intercellular communication by delivering their cargo to recipient cells, thereby modifying the target cells' signaling and function (Admyre et al., 2007; Hata et al., 2010; Lässer et al., 2011). Reports have shown that colostrum and milk miRNA are stable under degradative conditions such as RNase digestion, low $\mathrm{pH}$, high temperature, and freeze-thaw cycles (Izumi et al., 2012; Pieters et al., 2015). Their stability under these conditions can be attributed to their packaging within exosomes. Further reports have demonstrated the beneficial biological effects of milk exosomes and their miRNA on various human cell lines, including monocytic leukemia cells, monocyte-derived dendritic cells, and colon, lung, and breast cancer cells (Näslund et al., 2014; Izumi et al., 2015; Wolf et al., 2015; Munagala et al., 2016). Although the bioactivity of bovine milk exosomes on human cells has been demonstrated, the role of bovine colostrum- and milk-derived exosomes from different immune response phenotypes in regulating human intestinal cell function is undetermined. Based on previous knowledge of the biological effects of bovine colostrum and milk exosomes containing miRNA, along with established differences in HIR colostrum and milk quality, it was hypothesized that colostrum and milk exosomes containing miRNA isolated from $\mathrm{H}$ immune responder cows are functionally active at the gut mucosal interface, and promote the maintenance of the intestinal epithelial barrier compared with colostrum and milk exosomes from A and L immune responders. The specific objectives of this study were to (1) characterize and confirm the presence of exosomes in colostrum and milk from $\mathrm{H}, \mathrm{A}$, and $\mathrm{L}$ immune responders; (2) evaluate the uptake of exogenous exosomes from $\mathrm{H}, \mathrm{A}$, and L immune responder colostrum and milk by human cancer intestinal epithelial cells; (3) determine whether exosomes from $\mathrm{H}$ immune responder colostrum and milk promote intestinal cell viability compared with those from A and L immune responders; and (4) evaluate whether exosomes from $\mathrm{H}$ immune responders trigger apoptosis of human cancer intestinal epithelial cells. This study was designed to help better understand the functional role of colostrum and milk exosomes from dairy cows with different immune response phenotypes in regulating human intestinal epithelial cells.

\section{MATERIALS AND METHODS}

\section{Samples}

Colostrum and milk samples $(250 \mathrm{~mL}$ each) were collected (on the day of calving and 5-6 d postcalving, respectively) from healthy Holstein cows previously classified using EBV as $\mathrm{H}, \mathrm{A}$, or L immune responders from the University of Guelph's Elora Dairy Innovation Centre (Supplemental Table S1; https://doi .org/10.3168/jds.2020-18405). Briefly, EBV for both antibody- and cell-mediated immune responses allowed identification of cows as H-H, A-A, or L-L for both traits (Thompson-Crispi et al., 2012). For this study, $\mathrm{H}-\mathrm{H}$ cows were selected with EBV around +1.0 , and L-L cows were selected for EBV around -1.0. The A-A cows had EBV as close to zero as possible while attempting to say within the range of +0.5 and -0.5 . Samples were stored at $-80^{\circ} \mathrm{C}$ until the time of analysis. Three samples of both colostrum and milk for each immune response phenotype were used for subsequent experiments for a total of 9 colostrum and 9 milk samples.

\section{Isolation of Colostrum and Milk Exosomes}

Colostrum and milk exosomes containing miRNA were isolated through successive ultracentrifugation (Atalla et al., 2016; Ross et al., 2016). Briefly, samples were centrifuged for $30 \mathrm{~min}$ at $5,000 \times g$ and $4^{\circ} \mathrm{C}$. The supernatant was diluted with $1 \times$ sterile PBS $(\mathrm{pH} 7.4$, Thermo Fisher Scientific, Waltham, MA) at a ratio of 1:2 and centrifuged for $1 \mathrm{~h}$ at $12,000 \times g$ and $4^{\circ} \mathrm{C}$. The supernatant was then subjected to 3 consecutive ultracentrifugation steps $(35,000,70,000$, and $100,000 \times g$ for $1 \mathrm{~h}$ each at $4^{\circ} \mathrm{C}$ ) to purify exosomes. Resultant pellets were resuspended in approximately $38 \mathrm{~mL}$ of PBS and centrifuged again for $1 \mathrm{~h}$ at 100,000 $\times \mathrm{g}$ and $4^{\circ} \mathrm{C}$ to wash the pellet. After washing, pellets were weighed and resuspended in a volume of PBS equivalent to their weights, and total exosomal protein was quantified using Pierce BCA protein assay (Thermo Fisher Scientific). Isolated exosomes were then stored in $100-\mu \mathrm{L}$ aliquots at $-80^{\circ} \mathrm{C}$ until use in future experiments (Yamada et al., 2012; Momen-Heravi et al., 2013).

\section{Western Blotting of Colostrum and Milk Exosomes}

Colostrum and milk exosomes were characterized by western blot analysis for commonly expressed exosomal proteins (CD9, CD63, CD81, and heat shock protein 70 ; Hsp70). Exosomes were first lysed in Triton X-100 [1\% Triton-X-100 detergent (Bio-Rad, Mississauga, Canada), Tris base, and sodium chloride (Oxoid, Ther- 
mo Fisher Scientific)] cell lysis buffer containing Roche mini complete protease inhibitor (Roche, Mannheim, Germany) for $5 \mathrm{~min}$. To further lyse the exosomes, samples were sonicated in a water bath at room temperature 3 times for 5 min with brief vortexing in between. Samples were then centrifuged for 5 min at $13,000 \times g$ at room temperature. Exosome lysate was transferred to clean microfuge tubes and stored on ice, and total protein in the lysate was quantified using a Pierce BCA protein assay (Thermo Fisher Scientific). Laemmli buffer (prepared in the lab using $62.5 \mathrm{mM}$ Tris-HCl, $\mathrm{pH}$ $6.8,2 \%$ SDS, $25 \%$ glycerol, $0.01 \%$ bromophenol blue, and $5 \%$ b-mercaptoethanol) was added to samples at a $1: 1$ ratio and heated to $100^{\circ} \mathrm{C}$ for $10 \mathrm{~min}$. Samples (10-20 $\mu \mathrm{g}$ of protein per well) were loaded onto a $12 \%$ acrylamide gel, and proteins were separated by electrophoresis, followed by transfer to $0.22-\mu \mathrm{m}$ polyvinylidene difluoride membranes (Bio-Rad). To ensure equal loading of protein per well, polyvinylidene difluoride membranes were stained with Ponceau red for 5 min, gently rinsed with distilled water for $30 \mathrm{~s}$, and imaged using the ChemiDoc MP system (Bio-Rad). Membranes were then washed in Tris-buffered saline + Tween (TBS$\mathbf{T}$; Bio-Rad) for $15 \mathrm{~min}$ to remove the Ponceau stain. Membranes were blocked with $0.2 \%$ fish skin gelatin (Sigma-Aldrich, St. Louis, MO) in Tris-buffered saline for $1 \mathrm{~h}$ at room temperature, followed by washing with TBS-T. Exosomal proteins were detected using mouse anti-cow CD9 (ab3923, Abcam, Cambridge, UK), mouse anti-human CD63 (ab193349, Abcam), mouse anti-human TAPA1 (ab79559, Abcam), or mouse antihuman Hsp70 (ab2787, Abcam) diluted 1:1,000 in 0.2\% fish skin gelatin in TBS-T. Membranes were incubated with primary antibodies for approximately $18 \mathrm{~h}$ at $4^{\circ} \mathrm{C}$. After extensive washing with TBS-T, membranes were incubated with donkey anti-mouse IgG-HRP (ab6820, Abcam) secondary antibody diluted 1:10,000 in $0.2 \%$ fish skin gelatin in TBS- $\mathrm{T}$ for $1 \mathrm{~h}$ at room temperature. Concentration of antibody as reported by the manufacturer is included in Supplemental Table S2 (https://doi .org/10.3168/jds.2020-18405). Detected proteins were imaged using the ChemiDoc MP system (Lässer et al., 2011; Zonneveld et al., 2014).

\section{Caco-2 Cell Culture}

Human colorectal adenocarcinoma epithelial (Caco2, HTB-37) cells were purchased from American Type Culture Collection (ATCC, Cedarlane, Burlington, ON, Canada) and maintained in Eagle's essential medium (EMEM; ATCC) at $37^{\circ} \mathrm{C}, 5 \% \mathrm{CO}_{2}$ supplemented with $10 \%$ fetal bovine serum (FBS; Gibco, Waltham, MA), $100 \mathrm{U} / \mathrm{mL}$ penicillin, and $100 \mu \mathrm{g} / \mathrm{mL}$ streptomycin. Medium was changed every 2 to $3 \mathrm{~d}$. Cells were pas- saged once they reached approximately $70 \%$ confluence (4-5 d) and seeded at a density of approximately $1.0 \times$ $10^{6}$ cells per $\mathrm{T} 75-\mathrm{cm}^{2}$ flask (Lea, 2015). Before colostrum and milk exosome bioactivity on Caco-2 cells was assessed, medium was replaced with EMEM containing $10 \%$ exosome-depleted FBS and the previously mentioned antibiotics. The FBS was depleted of exosomes by centrifuging at $100,000 \times g$ for $18 \mathrm{~h}$ at $4^{\circ} \mathrm{C}$ as previously reported (Chiba et al., 2012; Shelke et al., 2014). The Caco-2 cells from passages 4 to 30 were used for bioactivity assays.

\section{Exosome Uptake Assay}

Uptake of colostrum or milk exosomes by Caco- 2 cells was assessed by labeling exosomes with a PKH67 green fluorescent cell linker kit for general cell membrane labeling (Sigma-Aldrich). Immediately before labeling, $4 \mu \mathrm{L}$ of PKH67 dye was added to $1 \mathrm{~mL}$ of Diluent C (provided in the PKH67 kit) to prepare the dye reagent (Lässer et al., 2011). A 100- $\mu \mathrm{L}$ aliquot of colostrum exosomes was added to the PKH67 dye reagent. As a control, the same volume of PBS was mixed with $1 \mathrm{~mL}$ of Diluent $\mathrm{C}$ and dye. The samples were gently mixed for $4 \mathrm{~min}$ on a shaker, followed by the addition of $2 \mathrm{~mL}$ of $1 \%$ exosome-depleted FBS (diluted in PBS) to bind excess dye for $1 \mathrm{~min}$ (Khatua et al., 2009; Lässer et al., 2011). The samples were then transferred to Beckman Ultra-Clear $13 \times 51-\mathrm{mm}$ ultracentrifuge tubes (Beckman Coulter, Pasadena, CA) and filled with exosomedepleted EMEM. Using the Beckman Coulter swinging bucket rotor $(\mathrm{SW} 55 \mathrm{Ti}, 6 \times 5 \mathrm{~mL}$ ), the samples were ultracentrifuged at $100,000 \times g$ at $4^{\circ} \mathrm{C}$ for $1 \mathrm{~h}$. After ultracentrifugation, the supernatant was discarded and the pellet was resuspended in exosome-depleted EMEM and transferred to clean ultracentrifuge tubes. The tubes were filled with exosome-depleted EMEM and ultracentrifuged once again at $100,000 \times g$ at $4^{\circ} \mathrm{C}$ for $1 \mathrm{~h}$ to remove unbound dye. After ultracentrifugation, the supernatant was discarded and the pellet was resuspended in the appropriate volume of exosome-depleted EMEM to give a concentration of $0.16 \mu \mathrm{g} / \mu \mathrm{L}$ labeled exosomes.

Prior to labeling, Caco-2 cells were seeded at a density of 60,000 cells/well in 24-well plates using exosome-depleted EMEM. Cells were allowed to adhere for approximately $18 \mathrm{~h}$, at which point they reached the desired confluence ( $\sim 70 \%$ confluence). Once exosomes were labeled and prepared for co-incubation, medium was removed from each of the wells and cells were washed with Dulbecco's PBS (DPBS; Gibco). Labeled exosomes $(0.16 \mu \mathrm{g} / \mu \mathrm{L})$, or the same volume of PKH67PBS control, were added to the appropriate wells and incubated for 2 or $24 \mathrm{~h}$ at either $37^{\circ} \mathrm{C}$ or $4^{\circ} \mathrm{C}$. Colostrum 
or milk exosomes from 3 cows (1 per immune response phenotype) were tested in triplicate. After co-incubation, cells were harvested using $0.25 \%$ trypsin- 0.53 $M$ EDTA solution (Gibco) to remove surface-bound exosomes (Franzen et al., 2014). Trypsinized cells were fixed in $4 \%$ formaldehyde for 10 min (Lässer et al., 2011; Izumi et al., 2015), followed by fixing cells to microscope slides (25,000 cells/slide) using the Shandon Cytospin 2 centrifuge (Shandon Scientific, Runcorn, UK). Once adhered to slides, cells were washed twice with DPBS, and $100 \mu \mathrm{L}$ of $0.1 \mathrm{M}$ ammonium chloride solution (Sigma-Aldrich) was added to the cells for 10 min to quench the formaldehyde reaction (Davis et al., 2014). Cells were gently washed again with DPBS. To label the nuclei of cells, $5 \mu \mathrm{L}$ of 7 -AAD dye (Molecular Probes, Eugene, OR) was diluted in $200 \mu \mathrm{L}$ of DPBS and added to the cells for $15 \mathrm{~min}$. Cells were then rinsed with DPBS and mounted using Vectashield (Vector Laboratories, Burlingame, CA; Izumi et al., 2015). Cellular uptake of exosomes was then visualized by fluorescence microscopy. Images were captured using an Axio Observer.A1 inverted microscope (Carl Zeiss, Oberkochen, Germany) and X-Cite 120Q microscope illumination system (Excelitas Technologies, Miamisburg, $\mathrm{OH}$ ). Images were analyzed using AxioVision software from Carl Zeiss (release 4.8.2).

\section{MTT Cell Viability and Proliferation Assay}

The Caco- 2 cells were seeded at a density of $6.0 \times$ $10^{4}$ cells/well in collagen-coated 24-well plates using EMEM containing 10\% exosome-depleted FBS, $100 \mathrm{U} /$ $\mathrm{mL}$ penicillin, and $100 \mu \mathrm{g} / \mathrm{mL}$ streptomycin (exosomedepleted medium). After allowing cells to adhere for approximately $18 \mathrm{~h}$, colostrum or milk exosomes from 9 cows (3 cows per immune response phenotype) were coincubated with Caco-2 cells at various exosomal protein concentrations $(0,0.001,0.005,0.025,0.125$, and 0.625 $\mu \mathrm{g} / \mu \mathrm{L}$ ) for 24,48 , and $72 \mathrm{~h}$ (Ahmed et al., 2015; Wolf et al., 2015; Munagala et al., 2016) in exosome-depleted medium. After each of the respective co-incubation time points, the medium was replaced with minimum essential medium containing no phenol red (Gibco) and $0.5 \mathrm{mg} / \mathrm{mL}$ MTT [3-(4,5-dimethylithiazol-2-yl)-2,5diphenyltetrazolium bromide] solution (Thermo Fisher Scientific) for $4 \mathrm{~h}$, followed by solubilization of formazan crystals with $0.01 M$ SDS-HCl for another $4 \mathrm{~h}$. In addition, MTT was added to wells containing only medium to serve as blank control and to Caco-2 cells that were not co-incubated with exosomes to serve as a negative control. Absorbance was read at $570 \mathrm{~nm}$ using a microplate spectrophotometer (BioTek PowerWave XS2, biotech Instruments, Winooski, VT). Each sample and control (no exosomes) were tested in triplicate.

\section{Caspase-3 In Vitro Apoptosis Assay}

Caspase 3 activity in Caco-2 cells after co-incubation with 0 and $0.125 \mu \mathrm{g} / \mu \mathrm{L}$ colostrum or milk exosomal protein for $48 \mathrm{~h}$ was assessed using a colorimetric caspase 3 assay kit (Sigma-Aldrich). The Caco- 2 cells were seeded at a density of $7.5 \times 10^{5}$ cells/flask in collagencoated T $25-\mathrm{cm}^{2}$ flasks using exosome-depleted medium and allowed to adhere for approximately $18 \mathrm{~h}$. Cells were co-incubated with $0.125 \mu \mathrm{g} / \mu \mathrm{L}$ exosomal protein for $48 \mathrm{~h}$ in exosome-depleted medium (Mahmoodzadeh Hosseini et al., 2014; Ahmed et al., 2015; Wolf et al., 2015; Munagala et al., 2016). According to the manufacturer's protocol and modified method (Mahmoodzadeh Hosseini et al., 2014), $3.0 \times 10^{6}$ cells were lysed in lysis buffer for $15 \mathrm{~min}$ on ice. Samples were then centrifuged for $10 \mathrm{~min}$ at $18,000 \times g$ at $4^{\circ} \mathrm{C}$. Cell lysates were collected and transferred to new microfuge tubes and stored at $-80^{\circ} \mathrm{C}$ until time of analysis. Using 96-well plates, $5 \mu \mathrm{L}$ of cell lysate and $10 \mu \mathrm{L}$ of caspase 3 substrate was added to the appropriate wells to measure caspase 3 activity in the cells after exosome co-incubation. Each sample $(\mathrm{n}=9)$ and control (no exosomes) were tested in triplicate. After $18 \mathrm{~h}$ of incubation at $37^{\circ} \mathrm{C}$, absorbance was read at $405 \mathrm{~nm}$ using a microplate spectrophotometer (BioTek PowerWave $\mathrm{XS} 2)$.

\section{Statistical Analysis}

Data from the MTT assay were analyzed using a linear mixed model (PROC MIXED, SAS version 9.4, SAS Institute Inc., Cary, NC). The statistical model was

$$
\begin{aligned}
y_{i j k l} & =\mu+\alpha_{i}+\beta_{j}+\gamma_{k}+\delta_{1}+\alpha \beta_{i j}+\alpha \gamma_{i k} \\
& +\beta \gamma_{j k}+\alpha \beta \gamma_{i j k}+\kappa\left(X_{i j k l}\right)+\varepsilon_{i j k l},
\end{aligned}
$$

where $\mathrm{y}_{\mathrm{ijkl}}=$ treatment optical density $(570 \mathrm{~nm})$ as an indicator of cell viability; $\mu=$ the grand population mean; $\alpha_{i}=$ immune response phenotype (L-L, A-A, or $\mathrm{H}-\mathrm{H}) ; \beta_{\mathrm{j}}=$ sample type (colostrum or milk); $\gamma_{\mathrm{k}}=$ duration of exosome co-incubation $(24,48$, or $72 \mathrm{~h}) ; \delta_{1}$ $=$ exosome treatment concentration $(\mu \mathrm{g} / \mu \mathrm{L}) ; \kappa\left(\mathrm{X}_{\mathrm{ijkl}}\right)$ $=$ relationship between treatment optical density and control optical density (covariate); and $\varepsilon_{\mathrm{ijkl}}=$ residual error. Normality was tested using Shapiro-Wilk test statistic and did not require a log-transformation. Interactions were tested and removed if nonsignificant in a hierarchical fashion. Values for F-tests are summarized in Supplemental Table S3 (https://doi.org/10 $.3168 / j d s .2020-18405)$. Results are presented as least squares means \pm standard errors. Significant differences between least squares means were determined by Stu- 


\section{Colostrum}

\section{Cow ID}

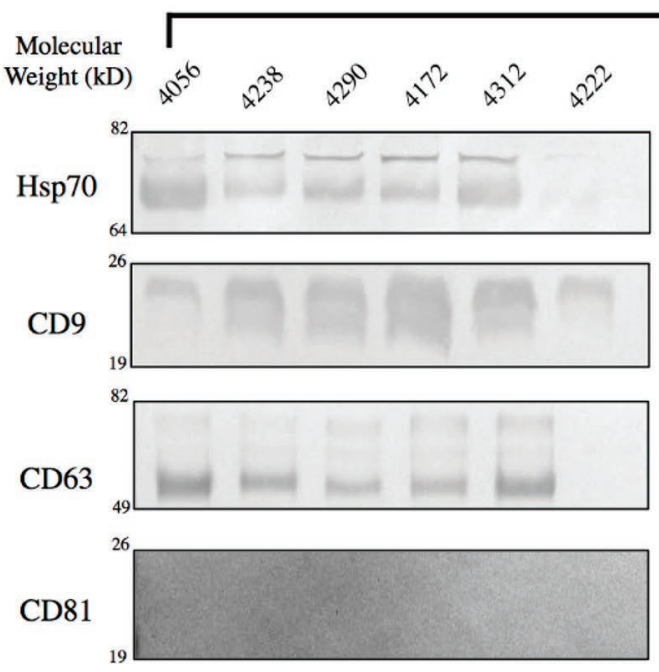

Milk

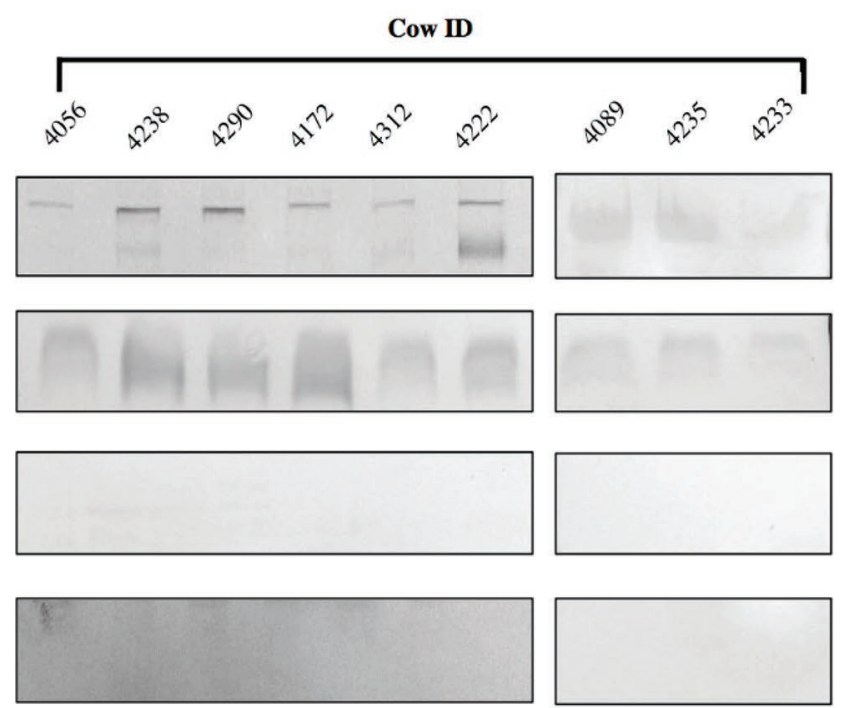

Figure 1. Western blot analysis of bovine colostrum and milk exosome isolates for Hsp70, CD63, CD9, and CD81.

dent's $t$-test, and $P \leq 0.05$ was considered significant. Data are presented using GraphPad Prism version 7.0 for Mac OS X (www.graphpad.com).

Data from the caspase 3 assay were analyzed using a linear mixed model (PROC MIXED, SAS Version 9.4, SAS Institute, Cary, NC). The statistical model was:

$$
\mathrm{y}_{\mathrm{ij}}=\mu+\alpha_{\mathrm{i}}+\beta_{\mathrm{j}}+\alpha \beta_{\mathrm{ij}}+\varepsilon_{\mathrm{ij}}
$$

where $\mathrm{y}_{\mathrm{ij}}=$ treatment optical density $(405 \mathrm{~nm})$ as an indicator of caspase 3 activity; $\mu=$ the grand population mean; $\alpha_{\mathrm{i}}=$ immune response phenotype (L-L, A-A, or $\mathrm{H}-\mathrm{H}) ; \beta_{\mathrm{j}}=$ sample type (colostrum or milk); $\varepsilon_{\mathrm{ij}}=$ residual error. Values for F-tests are summarized in Supplemental Table S4 (https://doi.org/10.3168/jds .2020-18405). Normality was tested using Shapiro-Wilk test statistic and data were log-transformed. Results are presented as medians with $95 \%$ confidence intervals. Significant differences between immune response groups were determined by Student's $t$-test. Differences $P \leq 0.05$ were considered significant. Data are presented using GraphPad Prism version 7.0 for Mac OS X.

\section{RESULTS}

\section{Characterization of Bovine Colostrum and Milk Exosomes}

Exosomes isolated from the colostrum and milk of 9 cows were characterized by western blotting for the commonly expressed exosomal proteins Hsp70, CD9, CD63, and CD81. Colostrum and milk exosomes were shown to express Hsp70 and CD9 but not CD81. The protein CD63 was detected only in milk (Figure 1).

\section{Uptake of Bovine Colostrum and Milk Exosomes}

Fluorescence microscopy demonstrated the uptake of labeled bovine colostrum and milk exosomes from each immune response phenotype by Caco- 2 cells after co-incubation (Figure 2C, E, and G; Figure 3C, E, and G). Cells cultured with the PKH67-PBS control showed an observable decrease in green fluorescence (Figure 2; Figure 3B). Similarly, co-incubation with labeled milk or colostrum exosomes resulted in decreased green fluorescence (Figure 2D, F, and $\mathrm{H}$ and Figure $3 \mathrm{D}, \mathrm{F}$, and $\mathrm{H}$, respectively).

\section{Cell Proliferation and Viability After Co-Incubation with Colostrum or Milk Exosomes}

Caco-2 cell proliferation assessed by trypan blue cell counts showed an increase in cell number over time when co-incubated with milk exosomes compared with incubation with exosome-depleted cell culture medium. Cell counts also demonstrated that Caco- 2 cells did not reach their proposed population doubling time when co-incubated with milk exosomes (Figure 4).

The MTT data indicated that Caco-2 cell viability remained significantly higher after 24 and $72 \mathrm{~h}$ of co- 
No PKH67 dye

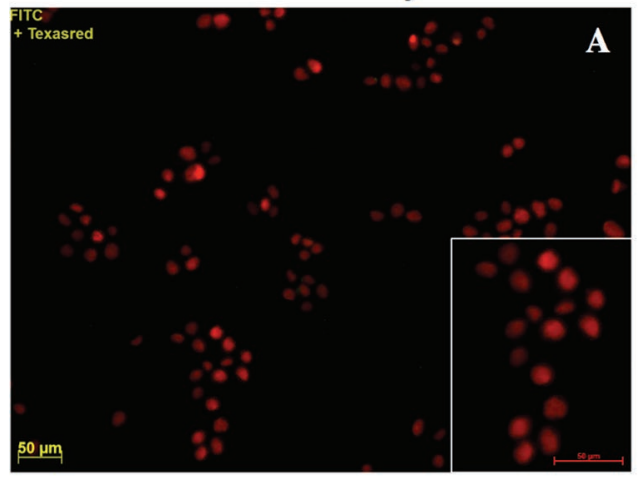

Milk exosomes $37^{\circ} \mathrm{C}$
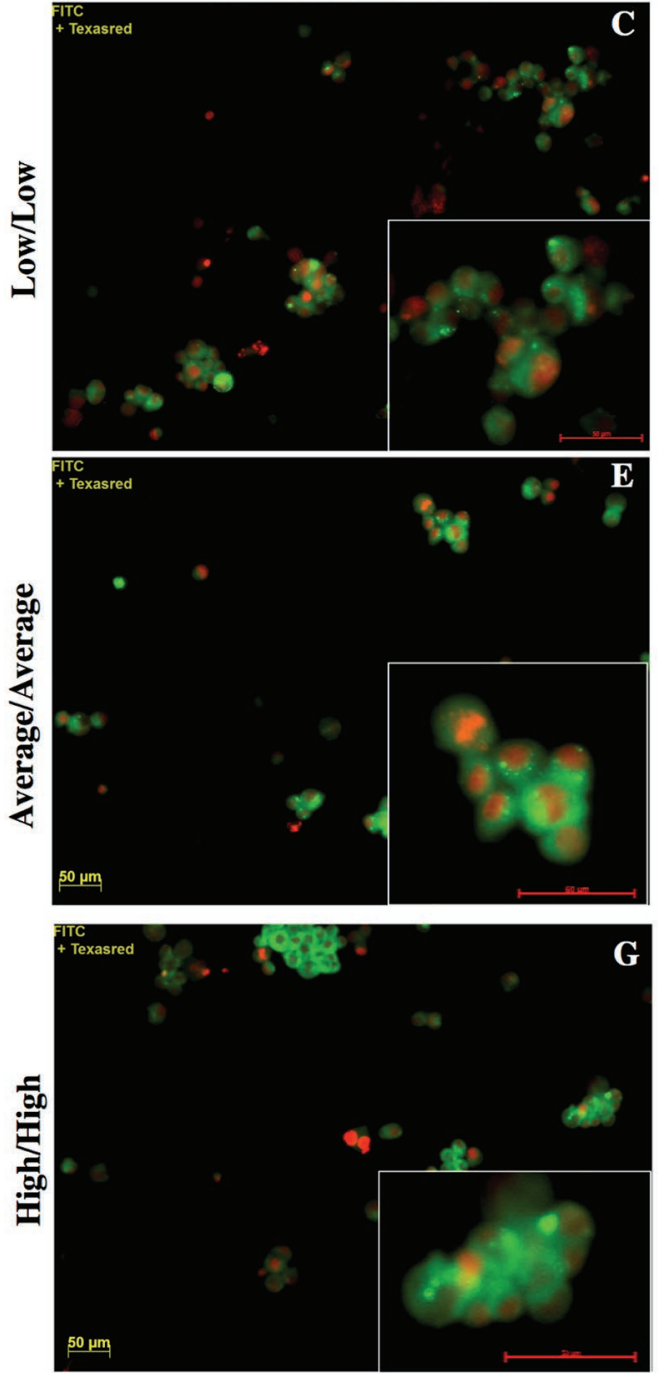

PBS-PKH67 dye

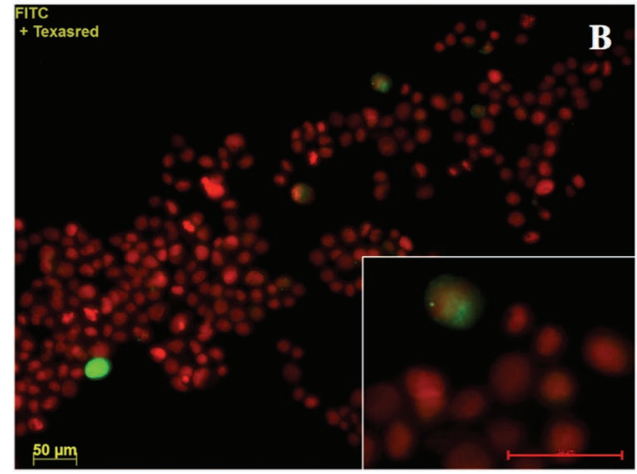

Milk exosomes $4^{\circ} \mathrm{C}$
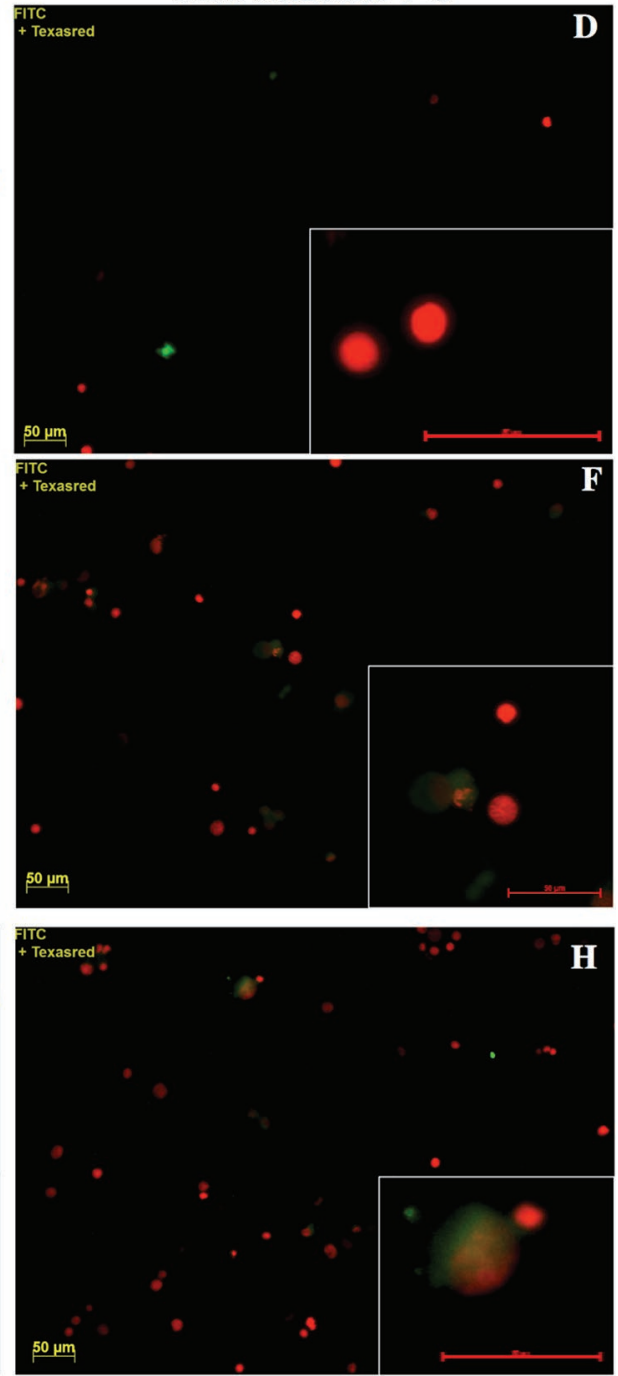

Figure 2. Uptake of bovine milk exosomes isolated from high, average, and low immune responders by human cancer intestinal epithelial cells (Caco-2). Scale bars represent $50 \mu \mathrm{m}$. Photographs were obtained using an Axio Observer.A1 inverted microscope (Carl Zeiss, Oberkochen, Germany) and X-Cite 120Q microscope illumination system (Excelitas Technologies, Miamisburg, OH) at 200× magnification. 
No PKH67 dye

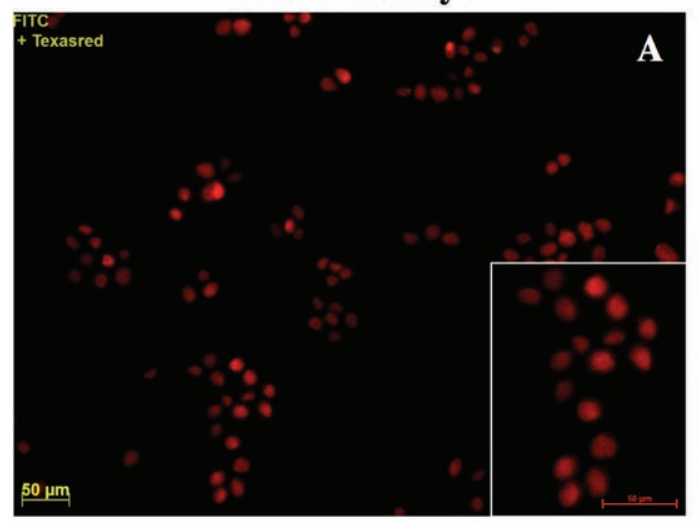

Colostrum exosomes $37^{\circ} \mathrm{C}$
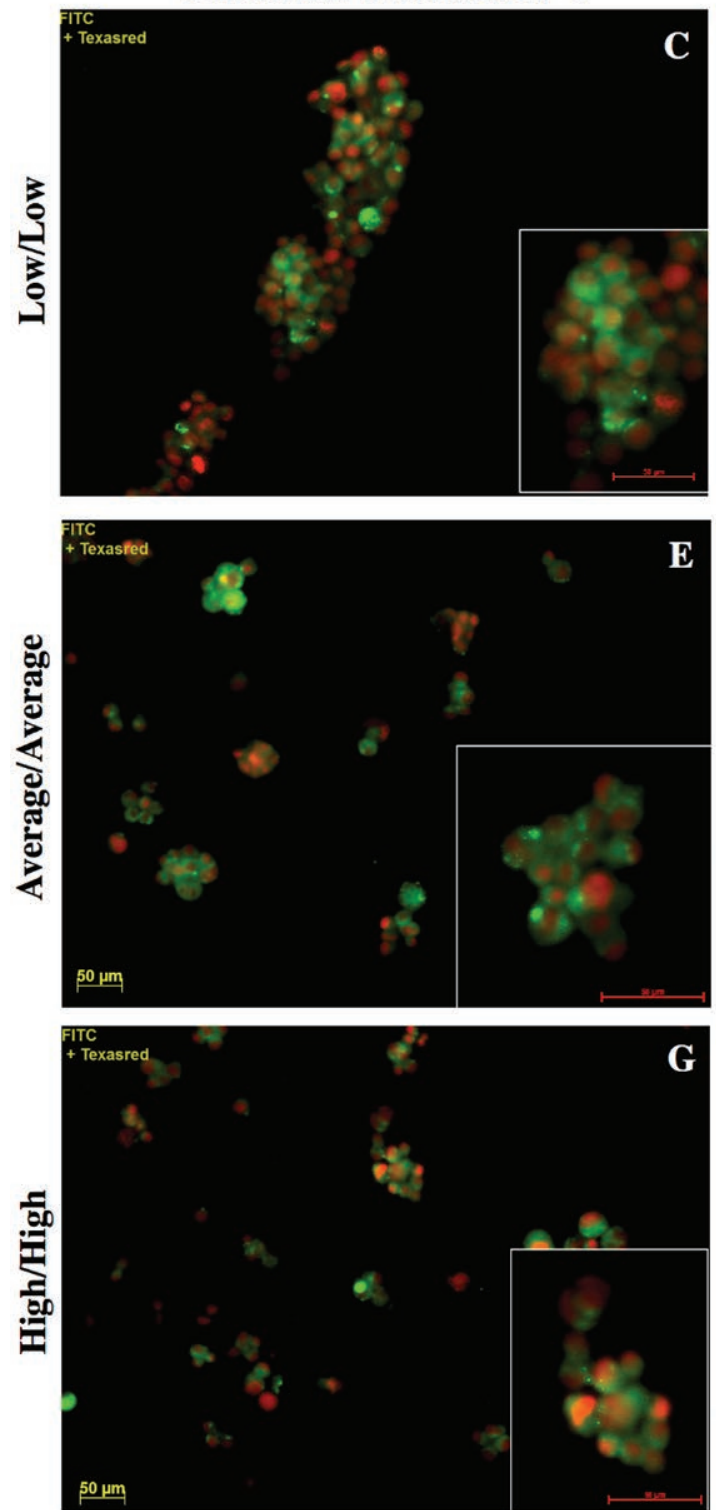

PBS-PKH67 dye

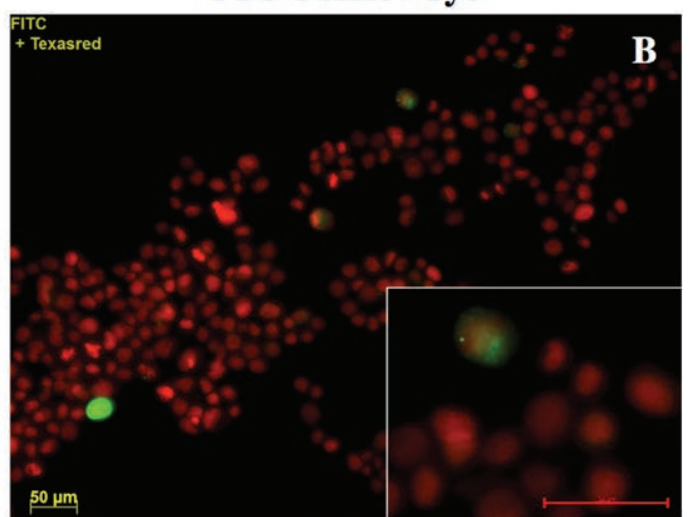

Colostrum exosomes $4^{\circ} \mathrm{C}$
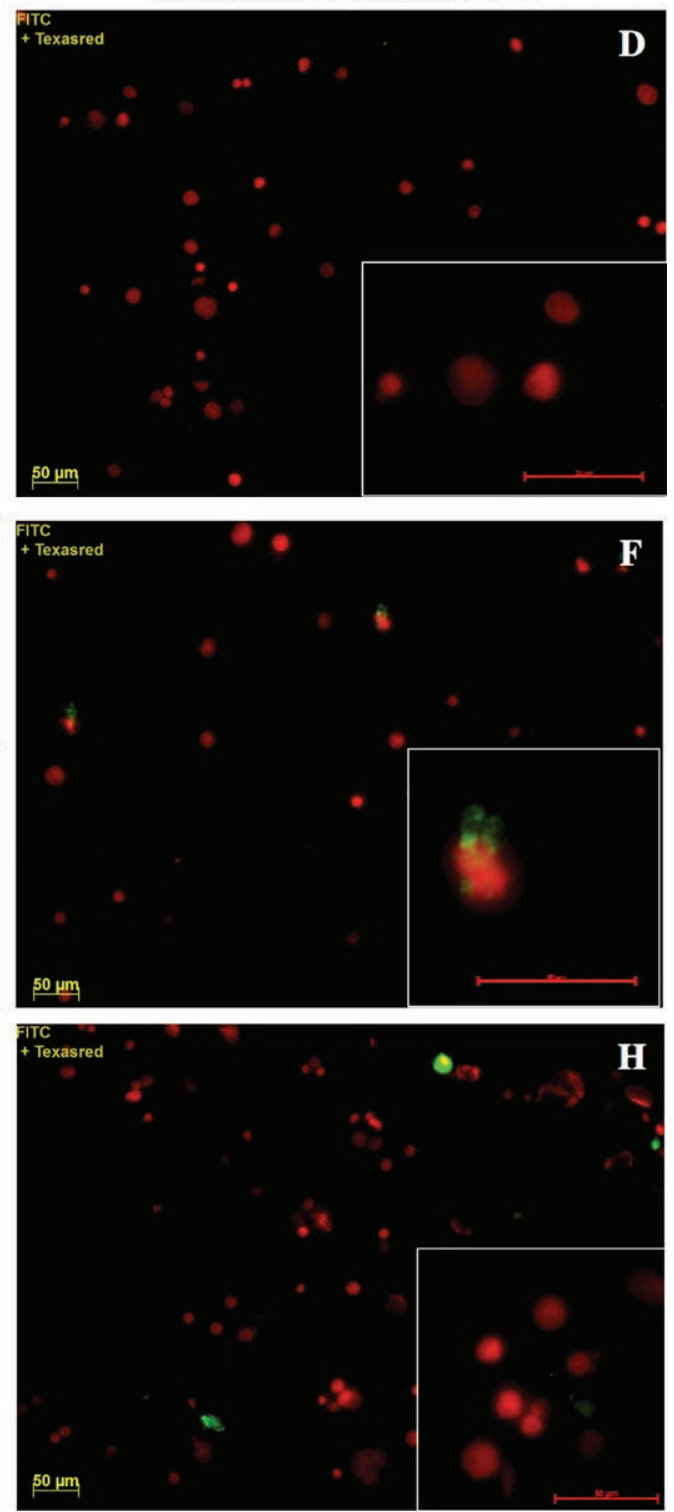

Figure 3. Uptake of bovine colostrum exosomes isolated from high, average, and low immune responders by human cancer intestinal epithelial cells (Caco-2). Scale bars represent $50 \mu \mathrm{m}$. Photographs were obtained using an Axio Observer.A1 inverted microscope (Carl Zeiss, Oberkochen, Germany) and X-Cite 120Q microscope illumination system (Excelitas Technologies, Miamisburg, OH) at 200× magnification. 


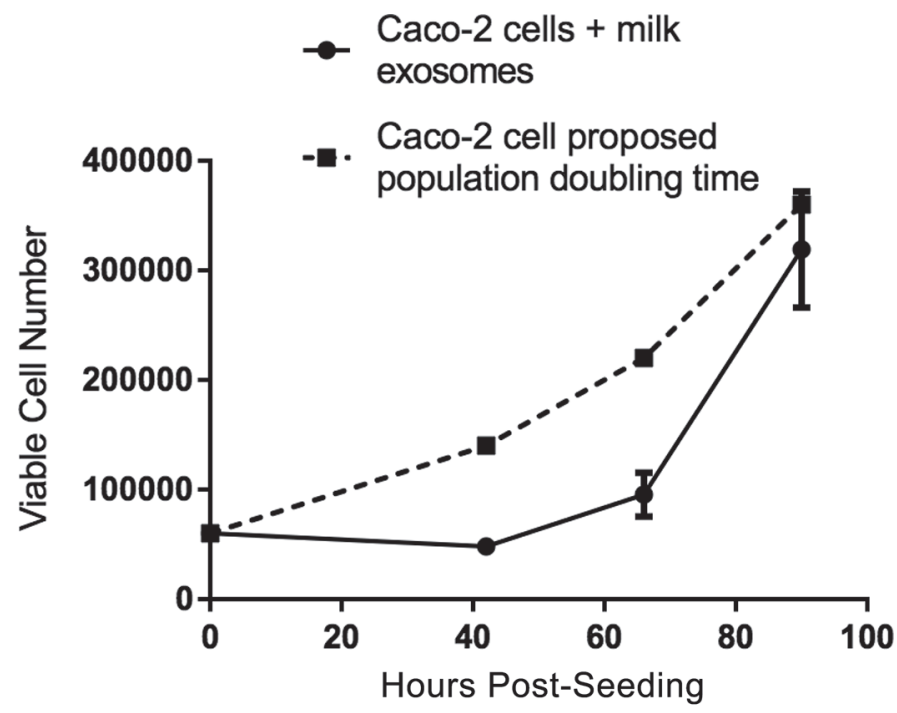

Figure 4. Assessment of human cancer intestinal epithelial cells (Caco-2) proliferation by trypan blue after coculture with bovine milk exosomes for 24,48 , and $72 \mathrm{~h}$. Dashed line represents the proposed population doubling time of Caco-2 cells according to the American Type Culture Collection product manual.

incubation with milk exosomes compared with colostrum exosomes (Figure 5). Co-incubation with milk exosomes from $\mathrm{H}$ immune responders resulted in significantly greater cell viability than co-incubation with $\mathrm{L}$ immune responder milk exosomes for 24 and $72 \mathrm{~h}$ but not $48 \mathrm{~h}$. Cell viability after co-incubation with A

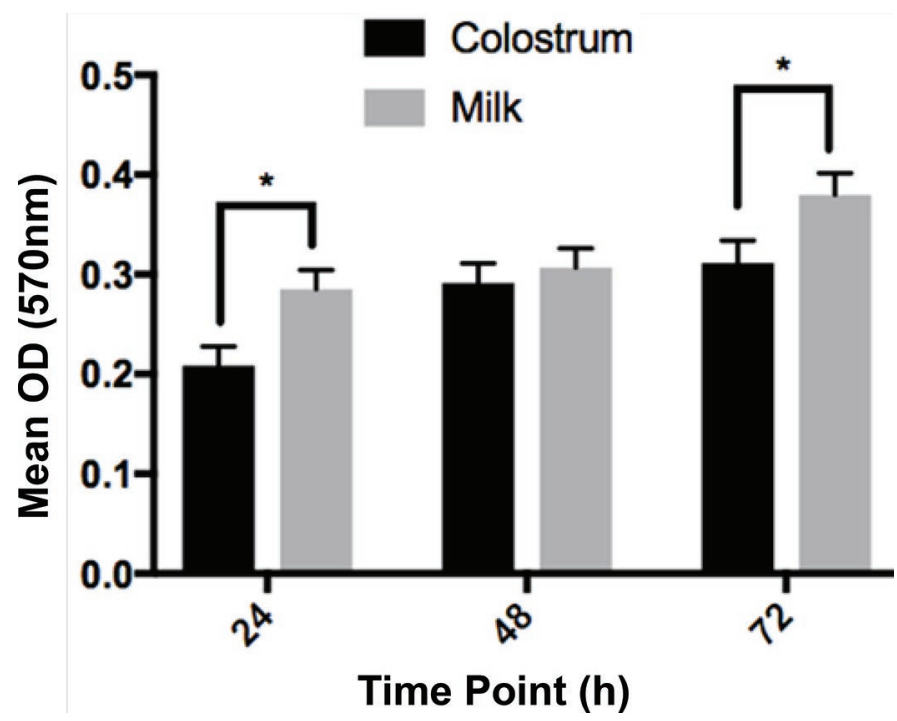

Figure 5. The MTT cell viability of human cancer intestinal epithelial (Caco-2) after treatment with bovine colostrum or milk exosomes for 24, 48, and $72 \mathrm{~h}$. Data are presented as mean optical density \pm SEM using GraphPad Prism 7.0 (GraphPad Software, La Jolla CA). $\mathrm{n}=9$ biological replicates per sample type. ${ }^{*} P<0.05$ was considered significant. immune responder milk exosomes was also significantly greater than co-incubation with $\mathrm{L}$ immune responder milk exosomes for $72 \mathrm{~h}$ (Figure 6A). With regards to colostrum exosomes, co-incubation with those from $\mathrm{H}$ immune responders resulted in significantly greater cell viability than co-incubation with $\mathrm{L}$ immune responder colostrum exosomes for 24, 48, and $72 \mathrm{~h}$ (Figure 6B).

\section{Caspase 3 Activity After Co-Incubation with Bovine Colostrum or Milk Exosomes}

Caspase 3 activity in Caco-2 cells after co-incubation with milk exosomes from $\mathrm{H}$, A, or $\mathrm{L}$ immune responders was not significantly different from the control (Figure 7A). Caspase 3 activity after co-incubation with L immune responder colostrum exosomes was significantly greater than the control, but there were no significant differences between the control and $\mathrm{H}$ or $\mathrm{A}$ immune responders or between the immune response phenotypes (Figure 7B).

\section{DISCUSSION}

In the current study, exosomes were isolated from $\mathrm{H}$, A, and L immune responder colostrum and milk and characterized by the expression of CD9 and Hsp70 using western blot analysis. The protein CD63 is typically expressed in milk exosome isolates (Reinhardt et al., 2012; Izumi et al., 2015; Wolf et al., 2015; Munagala et al., 2016; Yu et al., 2017). However, in this study and previous work by this group (Atalla et al., 2016), CD63 was not detected in milk exosomes. This observation could be attributed to differences in exosome isolation methods and milk sources by other researchers. These results further highlight the importance of verifying exosome isolation by evaluating expression of various exosome proteins.

Fluorescent microscopy images showed that colostrum and milk exosomes from $\mathrm{H}, \mathrm{A}$, and L immune responders were internalized by Caco- 2 cells, suggesting that bovine exosomes and their cargo can interact with and potentially modulate the human intestinal epithelium. These results are supported by recent studies demonstrating the uptake of bovine milk exosomes by human macrophages (Izumi et al., 2015), lung cancer cells (Munagala et al., 2016), and Caco-2 cells (Wolf et al., 2015).

In this study, there were no differences in uptake of colostrum and milk exosomes from $\mathrm{H}, \mathrm{A}$, and L immune responder cows. However, Caco-2 cell viability was significantly greater when co-incubated with colostrum or milk exosomes from $\mathrm{H}$ immune responder cows compared with L immune responders. Our group previously demonstrated differential expression of miR-21, 

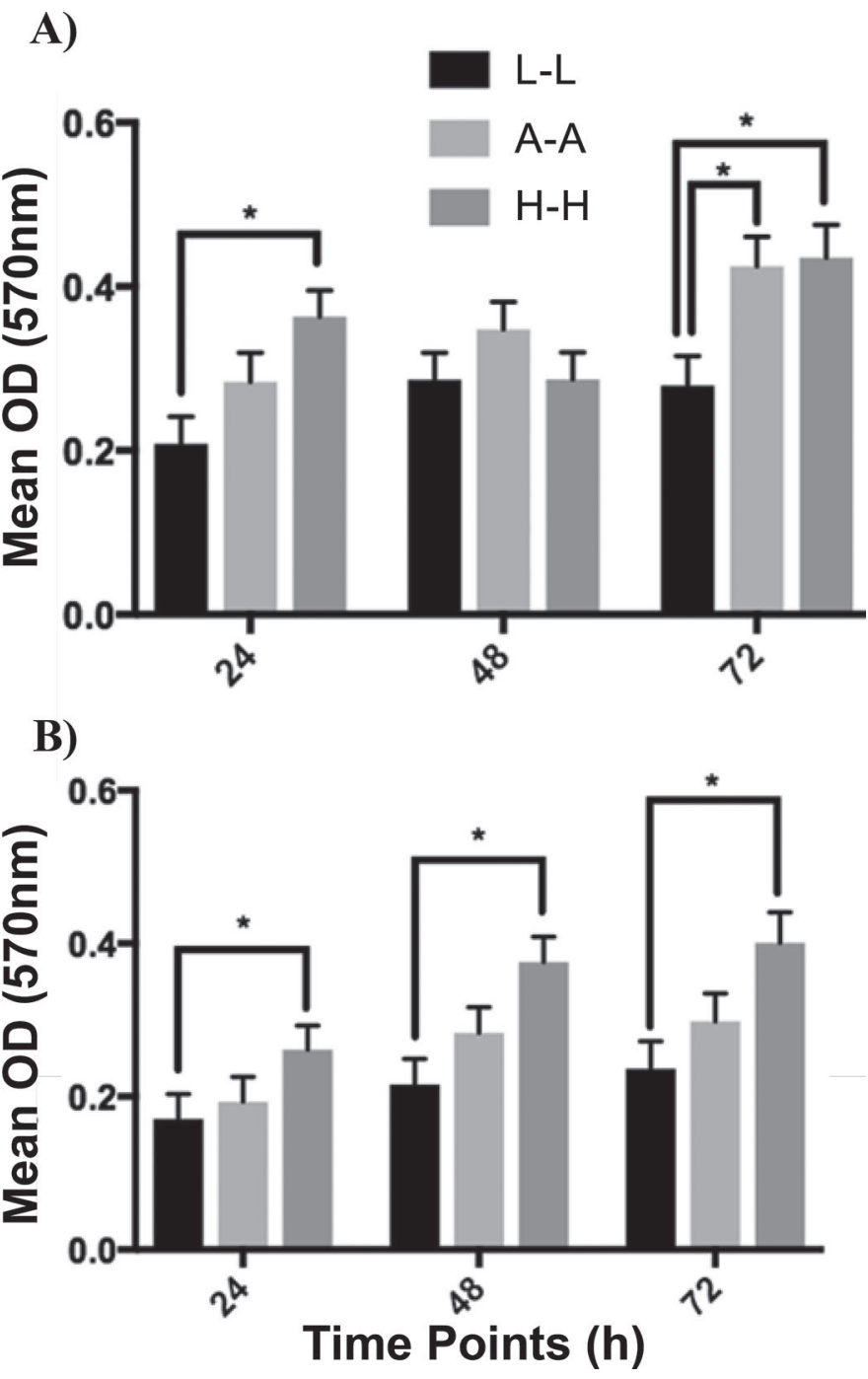

Figure 6. The MTT cell viability of human cancer intestinal epithelial (Caco-2) cell viability after treatment with 0.001 to $0.625 \mu \mathrm{g} /$ $\mu \mathrm{L}$ bovine milk (A) or colostrum exosomes (B) from low, average, or high immune responders for 24,48 , and $72 \mathrm{~h}$. Data are presented as mean optical density \pm SEM using GraphPad Prism 7.0 (GraphPad Software, La Jolla, CA). L-L = low-low; A-A = average-average; H-H $=$ high-high. $\mathrm{n}=3$ biological replicates per immune response phenotype. ${ }^{*} P<0.05$ was considered significant.

-26a, -29b, -148a, and -155 between colostrum and milk exosomes as well as those isolated from different immune response phenotypes (Atalla et al., 2016). These miRNA have been shown to regulate proliferation and apoptosis of various colon cancer cell lines (Zhang et al., 2011; Konishi et al., 2015; Qu et al., 2015; Yuan et al., 2015; Nedaeinia et al., 2016) and may contribute the differences in Caco-2 cell viability observed in this study.

This study indicates that although colostrum and milk exosomes enhanced cell viability, they do not stimulate oncogenic proliferation of Caco-2 cells when
A)

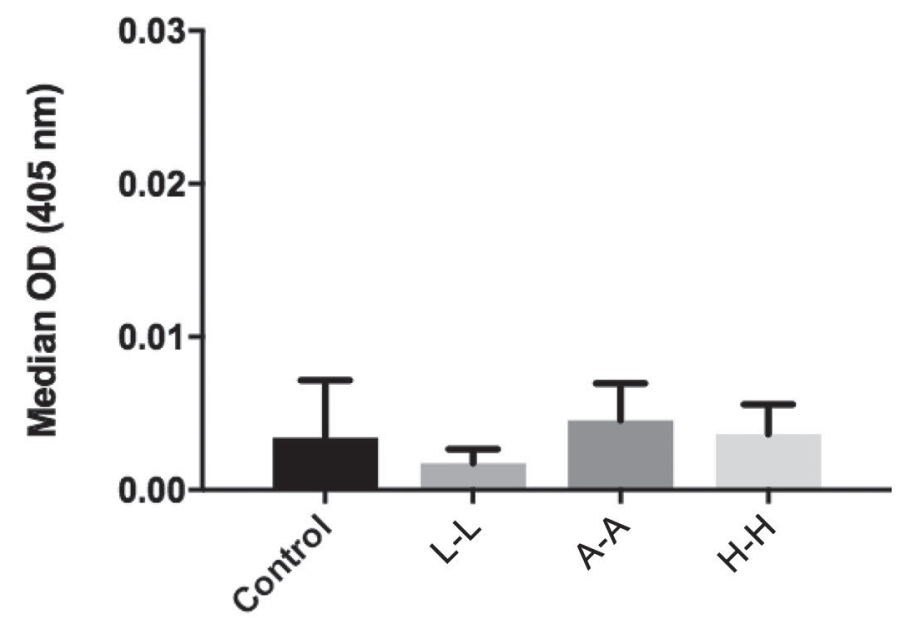

B)

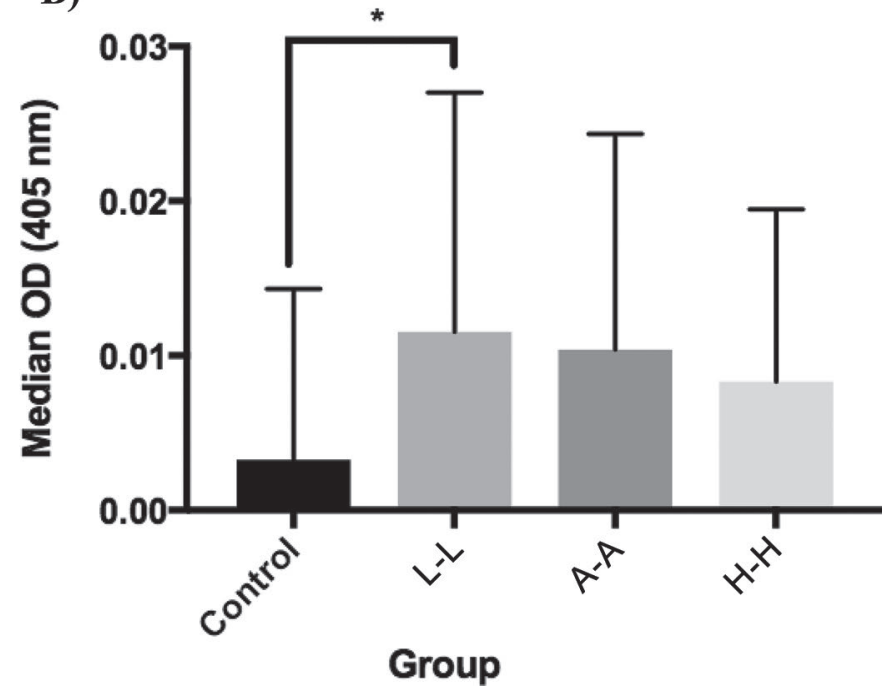

Figure 7. Caspase 3 activity in human cancer intestinal epithelial (Caco-2) cells after coculture with $0.125 \mu \mathrm{g} / \mu \mathrm{L}$ bovine milk (A) or colostrum exosomes (B) from low, average, or high immune responders for $48 \mathrm{~h}$. Data are presented as medians with $95 \%$ confidence intervals using GraphPad Prism 7.0 (GraphPad Software, La Jolla, CA). L-L = low-low; A-A = average-average; $\mathrm{H}-\mathrm{H}=$ high-high. $\mathrm{n}=3$ biological replicates per immune response phenotype; control represents caspase 3 activity in cells cultured without exosomes. ${ }^{*} P<0.05$ was considered significant.

supplemented with exosome-depleted medium. In view of a previous observation that extracellular vesicledepleted fetal bovine and human sera have reduced capacity to support cell growth (Eitan et al., 2015), it is plausible that exogenous supplementation of bovine colostrum and milk exosomes was adequate to support Caco-2 survival and proliferation up to $72 \mathrm{~h}$. Given the tendency for Caco-2 cells to differentiate into normal enterocyte-like cells of the small intestine, future work should consider whether these cells maintain their cancerous phenotype when incubated with colostrum and 
milk exosomes from different immune responder cows to elucidate whether these exosomes increase the risk of proliferative cancer in humans.

Results from this study also show that bovine colostrum and milk exosomes from different immune response phenotypes do not induce apoptosis of Caco-2 cells, with the exception of $\mathrm{L}$ immune responder colostrum exosomes, whereby very low caspase 3 activity was observed after co-incubation with these exosomes. Low detection to almost lack of caspase 3 activity after co-incubation with colostrum or milk exosomes from different immune response phenotypes could be attributed to several reasons, including (1) the presence of Hsp70 in colostrum and milk exosomes, which has been shown to inhibit the caspase 3 pathway in cells ( $\mathrm{Li}$ et al., 2000; Takayama et al., 2003); (2) the potential release of caspase 3-enriched vesicles from cells, thereby preventing cellular apoptosis (Böing et al., 2013); and (3) overexpression of oncogenic proteins and miRNA in Caco-2 cells (Ruemmele et al., 2003; Li et al., 2008; Kern et al., 2012), making it difficult to induce apoptosis of these cells after co-incubation with colostrum and milk exosomes containing a variety of cargo. Future work should consider the effect of Hsp70 inhibitors on colostrum and milk exosomes as well as assessing caspase 3 activity in culture supernatant compared with cell lysate. In view of the limitations of using Caco-2 cells, further studies are recommended to evaluate the functional role of colostrum and milk exosomes from cows with different immune response phenotypes on primary human intestinal epithelial cells to assess their role in the development of the human gut.

In summary, this study characterized expression of exosome surface markers in both the colostrum and milk of $\mathrm{H}, \mathrm{A}$, and $\mathrm{L}$ immune responder cows and demonstrated their ability to be taken up by human intestinal epithelial cells and maintain their metabolic activity while at the same time not being cytotoxic to these cells. This study further highlights that dairy products derived from cows with diverse immune response genetics could differ in their effect on human gut health.

\section{ACKNOWLEDGMENTS}

This research was funded by grants to B. A. Mallard by the Ontario Ministry of Agriculture, Food and Rural Affairs (Guelph, ON, Canada), Dairy Farmers of Ontario (Mississauga, ON, Canada), and Natural Sciences and Engineering Research Council of Canada (Ottawa, ON). This paper is also a contribution to the Food from Thought research program supported by the Canada First Research Excellence Fund (Ottawa, ON). The authors thank Laura Wright and staff at the Elora Research Station (University of Guelph, Ariss,
ON, Canada) for collecting samples used in this study and members of the Mallard laboratory (University of Guelph, Guelph, ON, Canada) for immune response phenotyping the animals and delivering samples. The authors also thank Keeley I. Burnside and Erin Syjueco for technical assistance with the experiments and William Sears for his assistance with the statistical analyses (University of Guelph). The authors report no conflicts of interest.

\section{REFERENCES}

Admyre, C., S. M. Johansson, K. R. Qazi, J.-J. Filén, R. Lahesmaa, M. Norman, E. P. A. Neve, A. Scheynius, and S. Gabrielsson. 2007. Exosomes with immune modulatory features are present in human breast milk. J. Immunol. 179:1969-1978. https://doi.org/ 10.4049/jimmunol.179.3.1969.

Ahmed, S. F., N. Das, M. Sarkar, U. Chatterjee, S. Chatterjee, and M. K. Ghosh. 2015. Exosome-mediated delivery of the intrinsic C-terminus domain of PTEN protects it from proteasomal degradation and ablates tumorigenesis. Mol. Ther. 23:255-269. https:// doi.org/10.1038/mt.2014.202.

Atalla, H., B. Mallard, and N. A. Karrow. 2016. Characterization of exosomal immune-related microRNAs in colostrum and milk from average, low and high immune responder cows. J. Anim. Sci. 94(Suppl. 4):74-75. https://doi.org/10.2527/jas2016 .94 supplement474a.

Bartel, D. P. 2004. MicroRNAs: Genomics, biogenesis, mechanism, and function. Cell 116:281-297. https://doi.org/10.1016/s0092 $-8674(04) 00045-5$

Böing, A. N., J. Stap, C. M. Hau, G. B. Afink, C. Ris-Stalpers, E. A. Reits, A. Sturk, C. J. F. van Noorden, and R. Nieuwland. 2013. Active caspase-3 is removed from cells by release of caspase-3-enriched vesicles. Biochim. Biophys. Acta 1833:1844-1852. https:// doi.org/10.1016/j.bbamcr.2013.03.013.

Chiba, M., M. Kimura, and S. Asari. 2012. Exosomes secreted from human colorectal cancer cell lines contain mRNAs, microRNAs and natural antisense RNAs, that can transfer into the human hepatoma HepG2 and lung cancer A549 cell lines. Oncol. Rep. 28:1551-1558. https://doi.org/10.3892/or.2012.1967.

Cartwright, S. L., F. Malchiodi, K. Thompson-Crispi, F. Miglior, and B. A. Mallard. 2017. Short communication: Prevalence of digital dermatitis in Canadian dairy cattle classified as high, average, or low antibody- and cell-mediated immune responders 100:84098413. https://doi.org/10.3168/jds.2016-12157.

Davis, A. S., A. Richter, S. Becker, J. E. Moyer, A. Sandouk, J. Skinner, and J. K. Taubenberger. 2014. Characterizing and diminishing autofluorescence in formalin-fixed paraffin-embedded human respiratory tissue. J. Histochem. Cytochem. 62:405-423. https:// doi.org/10.1369/0022155414531549.

Eckert, E., H. E. Brown, K. E. Leslie, T. J. DeVries, and M. A. Steele. 2015. Weaning age affects growth, feed intake, gastrointestinal development, and behavior in Holstein calves fed an elevated plane of nutrition during the preweaning stage. J. Dairy Sci. 98:6315-6326. https://doi.org/10.3168/jds.2014-9062.

Eitan, E., S. Zhang, K. W. Witwer, and M. P. Mattson. 2015. Extracellular vesicle-depleted fetal bovine and human sera have reduced capacity to support cell growth. J. Extracell. Vesicles 4:26373. https://doi.org/10.3402/jev.v4.26373.

Fleming, K., K. A. Thompson-Crispi, D. C. Hodgins, F. Miglior, M. Corredig, and B. A. Mallard. 2016. Short communication: Variation of total immunoglobulin $\mathrm{G}$ and $\beta$-lactoglobulin concentrations in colostrum and milk from Canadian Holsteins classified as high, average, or low immune responders. J. Dairy Sci. 99:2358-2363. https://doi.org/10.3168/jds.2015-9707.

Franzen, C. A., P. E. Simms, A. F. Van Huis, K. E. Foreman, P. C. Kuo, and G. N. Gupta. 2014. Characterization of uptake and in- 
ternalization of exosomes by bladder cancer cells. BioMed Res. Int. 2014:1-11. https://doi.org/10.1155/2014/619829.

Hata, T., K. Murakami, H. Nakatani, Y. Yamamoto, T. Matsuda, and N. Aoki. 2010. Isolation of bovine milk-derived microvesicles carrying mRNAs and microRNAs. Biochem. Biophys. Res. Commun. 396:528-533. https://doi.org/10.1016/j.bbrc.2010.04.135.

Haug, A., A. T. Høstmark, and O. M. Harstad. 2007. Bovine milk in human nutrition - A review. Lipids Health Dis. 6:25. https://doi .org/10.1186/1476-511X-6-25.

Hill, D. R., and D. S. Newburg. 2015. Clinical applications of bioactive milk components. Nutr. Rev. 73:463-476. https://doi.org/10.1093/ nutrit/nuv009.

Izumi, H., N. Kosaka, T. Shimizu, K. Sekine, T. Ochiya, and M. Takase. 2012. Bovine milk contains microRNA and messenger RNA that are stable under degradative conditions. J. Dairy Sci. 95:4831-4841. https://doi.org/10.3168/jds.2012-5489.

Izumi, H., M. Tsuda, Y. Sato, N. Kosaka, T. Ochiya, H. Iwamoto, K. Namba, and Y. Takeda. 2015. Bovine milk exosomes contain microRNA and mRNA and are taken up by human macrophages. J. Dairy Sci. 98:2920-2933. https://doi.org/10.3168/jds.2014-9076.

Jabed, A., S. Wagner, J. McCracken, D. N. Wells, and G. Laible. 2012. Targeted microRNA expression in dairy cattle directs production of $\beta$-lactoglobulin-free, high-casein milk. Proc. Natl. Acad. Sci. USA 109:16811-16816. https://doi.org/10.1073/pnas.1210057109.

Kern, H. B., B. F. Niemeyer, J. K. Parrish, C. A. Kerr, N. K. Yaghi, J. D. Prescott, A. Gutierrez-Hartmann, and P. Jedlicka. 2012. Control of microRNA-21 expression in colorectal cancer cells by oncogenic epidermal growth factor/Ras signaling and Ets transcription factors. DNA Cell Biol. 31:1403-1411. https://doi.org/ 10.1089/dna.2011.1469.

Khan, M. A., D. M. Weary, and M. A. G. von Keyserlingk. 2011. Invited review: Effects of milk ration on solid feed intake, weaning, and performance in dairy heifers. J. Dairy Sci. 94:1071-1081. https://doi.org/10.3168/jds.2010-3733.

Khatua, A. K., H. E. Taylor, J. E. Hildreth, and W. Popik. 2009. Exosomes packaging APOBEC3G confer human immunodeficiency virus resistance to recipient cells. J. Virol. 83:512-521. https://doi .org/10.1128/JVI.01658-08.

Konishi, H., M. Fujiya, N. Ueno, K. Moriichi, J. Sasajima, K. Ikuta, H. Tanabe, H. Tanaka, and Y. Kohgo. 2015. MicroRNA-26a and -584 inhibit the colorectal cancer progression through inhibition of the binding of hnRNP A1-CDK6 mRNA. Biochem. Biophys. Res. Commun. 467:847-852. https://doi.org/10.1016/j.bbrc.2015 .10 .055 .

Korst, M., C. Koch, J. Kesser, U. Müller, F. J. Romberg, J. Rehage, K. Eder, and H. Sauerwein. 2017. Different milk feeding intensities during the first 4 weeks of rearing in dairy calves: Part 1: Effects on performance and production from birth over the first lactation. J. Dairy Sci. 100:3096-3108. https://doi.org/10.3168/ jds.2016-11594.

Lässer, C., V. Seyed Alikhani, K. Ekström, M. Eldh, P. Torregrosa Paredes, A. Bossios, M. Sjöstrand, S. Gabrielsson, J. Lötvall, and H. Valadi. 2011. Human saliva, plasma and breast milk exosomes contain RNA: Uptake by macrophages. J. Transl. Med. 9:9. https: //doi.org/10.1186/1479-5876-9-9.

Lea, T. 2015. Caco-2 Cell Line. K. Verhoeckx, P. Cotter, I. LópezExpósito, C. Kleiveland, T. Lea, A. Mackie, T. Requena, D. Swiatecka, and H. Wichers, ed. Springer International Publishing, Cham, Switzerland.

Li, B. H., X. Z. Yang, P. D. Li, Q. Yuan, X. H. Liu, J. Yuan, and W. J. Zhang. 2008. IL-4/Stat6 activities correlate with apoptosis and metastasis in colon cancer cells. Biochem. Biophys. Res. Commun. 369:554-560. https://doi.org/10.1016/j.bbrc.2008.02.052.

Li, C. Y., J. S. Lee, Y. G. Ko, J. I. Kim, and J. S. Seo. 2000. Heat shock protein 70 inhibits apoptosis downstream of cytochrome c release and upstream of caspase-3 activation. J. Biol. Chem. https: //doi.org/10.1074/jbc.M906383199.

Li, Z., H. Liu, X. Jin, L. Lo, and J. Liu. 2012. Expression profiles of microRNAs from lactating and non-lactating bovine mammary glands and identification of miRNA related to lactation. BMC Genomics 13:731. https://doi.org/10.1186/1471-2164-13-731.
Liao, Y., X. Du, and B. Lönnerdal. 2010. miR-214 regulates lactoferrin expression and pro-apoptotic function in mammary epithelial cells. J. Nutr. 140:1552-1556. https://doi.org/10.3945/jn.110.124289.

Mahmoodzadeh Hosseini, H., A. A. Imani Fooladi, J. Soleimanirad, M. R. Nourani, S. Davaran, and M. Mahdavi. 2014. Staphylococcal entorotoxin $\mathrm{B}$ anchored exosome induces apoptosis in negative esterogen receptor breast cancer cells. Tumour Biol. 35:3699-3707. https://doi.org/10.1007/s13277-013-1489-1.

Mallard, B. A., M. Emam, M. Paibomesai, K. Thompson-Crispi, and L. Wagter-Lesperance. 2015. Genetic selection of cattle for improved immunity and health. Jpn. J. Vet. Res. https://doi.org/10 .14943/jjvr.63.suppl.s37.

Meale, S. J., S. C. Li, P. Azevedo, H. Derakhshani, T. J. DeVries, J. C. Plaizier, M. A. Steele, and E. Khafipour. 2017. Weaning age influences the severity of gastrointestinal microbiome shifts in dairy calves. Sci. Rep. 7:198. https://doi.org/10.1038/s41598-017 $-00223-7$.

Mills, S., R. P. Ross, C. Hill, G. F. Fitzgerald, and C. Stanton. 2011. Milk intelligence: Mining milk for bioactive substances associated with human health. Int. Dairy J. 21:377-401. https://doi.org/10 .1016/j.idairyj.2010.12.011.

Momen-Heravi, F., L. Balaj, S. Alian, P. Y. Mantel, A. E. Halleck, A. J. Trachtenberg, C. E. Soria, S. Oquin, C. M. Bonebreak, E. Saracoglu, J. Skog, and W. P. Kuo. 2013. Current methods for the isolation of extracellular vesicles. Biol. Chem. 394:1253-1262. https://doi.org/10.1515/hsz-2013-0141.

Munagala, R., F. Aqil, J. Jeyabalan, and R. C. Gupta. 2016. Bovine milk-derived exosomes for drug delivery. Cancer Lett. 371:48-61. https://doi.org/10.1016/j.canlet.2015.10.020.

Näslund, T. I., D. Paquin-Proulx, P. T. Paredes, H. Vallhov, J. K. Sandberg, and S. Gabrielsson. 2014. Exosomes from breast milk inhibit HIV-1 infection of dendritic cells and subsequent viral transfer to $\mathrm{CD}_{4}^{+} \mathrm{T}$ cells. AIDS 28:171-180. https://doi.org/10 .1097/QAD.0000000000000159.

Nedaeinia, R., M. Sharifi, A. Avan, M. Kazemi, L. Rafiee, M. GhayourMobarhan, and R. Salehi. 2016. Locked nucleic acid anti-MIR-21 inhibits cell growth and invasive behaviors of a colorectal adenocarcinoma cell line: LNA-anti-MIR as a novel approach. Cancer Gene Ther. 23:246-253. https://doi.org/10.1038/cgt.2016.25.

Ogorevc, J., T. Kunej, A. Razpet, and P. Dovc. 2009. Database of cattle candidate genes and genetic markers for milk production and mastitis. Anim. Genet. 40:832-851. https://doi.org/10.1111/j .1365-2052.2009.01921.x.

Pieters, B. C. H., O. J. Arntz, M. B. Bennink, M. G. A. Broeren, A. P. M. Van Caam, M. I. Koenders, P. L. E. M. Van Lent, W. B. Van Den Berg, M. De Vries, P. M. Van Der Kraan, and F. A. J. Van De Loo. 2015. Commercial cow milk contains physically stable extracellular vesicles expressing immunoregulatory TGF- $\beta$. PLoS One 10:e0121123. https://doi.org/10.1371/journal.pone.0121123.

Qu, Y. L., H. F. Wang, Z. Q. Sun, Y. Tang, X. N. Han, X. B. Yu, and K. Liu. 2015. Up-regulated miR-155-5p promotes cell proliferation, invasion and metastasis in colorectal carcinoma. Int. J. Clin. Exp. Pathol. 8:6988-6994.

Reinhardt, T. A., J. D. Lippolis, B. J. Nonnecke, and R. E. Sacco. 2012. Bovine milk exosome proteome. J. Proteomics 75:1486-1492. https://doi.org/10.1016/j.jprot.2011.11.017.

Ross, M., H. Atalla, and B. Mallard. 2016. Bioactivity of colostrum and milk exosomes containing microRNA from cows genetically selected as high, average and low immune responders based on their estimated breeding values. J. Anim. Sci. 94(Suppl_4):65-66. https://doi.org/10.2527/jas2016.94supplement465x.

Ruemmele, F. M., S. Schwartz, E. G. Seidman, S. Dionne, E. Levy, and M. J. Lentze. 2003. Butyrate induced Caco-2 cell apoptosis is mediated via the mitochondrial pathway. Gut 52:94-100. https:// doi.org/10.1136/gut.52.1.94.

Shelke, G. V., C. Lässer, Y. S. Gho, and J. Lötvall. 2014. Importance of exosome depletion protocols to eliminate functional and RNAcontaining extracellular vesicles from fetal bovine serum. J. Extracell. Vesicles 3:24783. https://doi.org/10.3402/jev.v3.24783.

Sun, Q., X. Chen, J. Yu, K. Zen, C. Y. Zhang, and L. Li. 2013. Immune modulatory function of abundant immune-related microR- 
NAs in microvesicles from bovine colostrum. Protein Cell 4:197210. https://doi.org/10.1007/s13238-013-2119-9.

Takayama, S., J. C. Reed, and S. Homma. 2003. Heat-shock proteins as regulators of apoptosis. Oncogene 22:9041-9047. https://doi .org/10.1038/sj.onc.1207114.

Théry, C., M. Ostrowski, and E. Segura. 2009. Membrane vesicles as conveyors of immune responses. Nat. Rev. Immunol. 9:581-593. https://doi.org/10.1038/nri2567.

Thompson-Crispi, K. A., M. Sargolzaei, R. Ventura, M. Abo-Ismail, F. Miglior, F. Schenkel, and B. A. Mallard. 2014. A genome-wide association study of immune response traits in Canadian Holstein cattle. BMC Genomics 15:559. https://doi.org/10.1186/1471-2164 $-15-559$.

Thompson-Crispi, K. A., A. Sewalem, F. Miglior, and B. A. Mallard. 2012. Genetic parameters of adaptive immune response traits in Canadian Holsteins. J. Dairy Sci. 95:401-409. https://doi.org/10 $.3168 /$ jds.2011-4452.

Wang, D., G. Liang, B. Wang, H. Sun, J. Liu, and L. L. Guan. 2016. Systematic microRNAome profiling reveals the roles of microRNAs in milk protein metabolism and quality: Insights on low-quality forage utilization. Sci. Rep. 6:21194. https://doi.org/10.1038/ srep21194.

Wolf, T., S. R. Baier, and J. Zempleni. 2015. The intestinal transport of bovine milk exosomes is mediated by endocytosis in human colon carcinoma Caco-2 cells and rat small intestinal IEC-6 cells. J. Nutr. 145:2201-2206. https://doi.org/10.3945/jn.115.218586.

Yamada, T., Y. Inoshima, T. Matsuda, and N. Ishiguro. 2012. Comparison of methods for isolating exosomes from bovine milk. J. Vet. Med. Sci. 74:1523-1525. https://doi.org/10.1292/jvms.12-0032.
Yu, S., Z. Zhao, L. Sun, and P. Li. 2017. Fermentation results in quantitative changes in milk-derived exosomes and different effects on cell growth and survival. J. Agric. Food Chem. 65:1220-1228. https://doi.org/10.1021/acs.jafc.6b05002.

Yuan, L., C. Zhou, Y. Lu, M. Hong, Z. Zhang, Z. Zhang, Y. Chang, C. Zhang, and X. Li. 2015. IFN- $\gamma$-mediated IRF1/miR-29b feedback loop suppresses colorectal cancer cell growth and metastasis by repressing IGF1. Cancer Lett. 359:136-147. https://doi.org/10 .1016/j.canlet.2015.01.003.

Zhang, H., Y. Li, Q. Huang, X. Ren, H. Hu, H. Sheng, and M. Lai. 2011. MiR-148a promotes apoptosis by targeting Bcl-2 in colorectal cancer. Cell Death Differ. 18:1702-1710. https://doi.org/10 $.1038 /$ cdd.2011.28.

Zonneveld, M. I., A. R. Brisson, M. J. C. van Herwijnen, S. Tan, C. H. A. van de Lest, F. A. Redegeld, J. Garssen, M. H. M. Wauben, and E. N. M. Nolte-'t Hoen. 2014. Recovery of extracellular vesicles from human breast milk is influenced by sample collection and vesicle isolation procedures. J. Extracell. Vesicles 3:24215. https:/ /doi.org/10.3402/jev.v3.24215.

\section{ORCIDS}

Mikayla Ross (ํ) https://orcid.org/0000-0002-4224-1174

Heba Atalla $\odot$ https://orcid.org/0000-0001-5340-5560

Niel Karrow @ () https://orcid.org/0000-0003-2240-3022

Bonnie A. Mallard (๑) https://orcid.org/0000-0002-9853-905X 